\title{
ANTIMICROBIAL ACTIVITY AND POTENTIAL USE OF MONOTERPENES AS TROPICAL FRUITS PRESERVATIVES
}

\author{
Roxana Garcia $^{1,3}$; Eliomara S.S. Alves ${ }^{1}$; Mirella P. Santos ${ }^{1}$; Glória M.F. Viégas Aquije ${ }^{1}$; A. Alberto R. Fernandes ${ }^{1}$; \\ Reginaldo B. dos Santos ${ }^{1}$; Jose A. Ventura ${ }^{1,2}$; Patricia M.B. Fernandes ${ }^{1 *}$
}

${ }^{1}$ Núcleo de Biotecnologia, Universidade Federal do Espírito Santo, Vitória, ES, Brasil; ${ }^{2}$ Instituto Capixaba de Pesquisa, Assistência Técnica e Extensão Rural, Vitória, ES, Brasil; ${ }^{3}$ Departamento de Microbiologia, Instituto Cubano de Investigaciones de los Derivados de la Caña de Azúcar, Havana, Cuba

Submitted: May 11, 2007; Approved: November 25, 2007.

\begin{abstract}
Banana, papaya and pineapple are the most consumed tropical fruits in the world, being Brazil one of the main producers. Fungi Colletotrichum musae, Colletotrichum gloeosporioides and Fusarium subglutinans f.sp. ananas cause severe post harvest diseases and losses in fruits quality. The aim of this work was to evaluate the effectiveness of five monoterpenes to inhibit the mycelial growth and conidia germination of these three phytopathogens. The monoterpenes citral, citronellal, L-carvone, isopullegol and $\alpha$-pinene were diluted in ethanol to final concentrations from 0.2 to $1 \%$. All monoterpenes were found to inhibit the growth of the three studies fungi in a dose-dependent manner. Citral was the most effective of the oils tested and showed potent fungicidal activity at concentrations above $0.5 \%$. Also, in vivo evaluation with these tropical fruits demonstrated the efficiency of citral to inhibit fungal growth. These results indicate the potential use of citral as a natural pesticide control of post-harvest fruit diseases.
\end{abstract}

Key words: biocontrol, essential oils, banana, papaya, pineapple, plant diseases

\section{INTRODUCTION}

Plant-derived essential oils containing monoterpenoids have been used as antifungal drugs since ancient times, depending both on application method and dose manner (23). Studies on the antimicrobial activity of essential oils from aromatic species used in Brazil shows that the oils present one or more active fraction, being monoterpenes the major constituents (17). Also, Shimizu et al., 2006 stressed the importance of the analysis of the chemical composition of the essential oil to elucidate the pharmacological mechanisms in order to uses this kind of oils in medical application. Several authors concluded that as lipophilic agents they execute their action at membrane integrity level, affecting embedded enzymes and fatty acid composition (14); being citral and $\alpha$-pinene the most referred of these hydrocarbons.

Effects of citral in a broad spectrum of post-harvest and aflatoxigenic pathogens have been well documented, showing a strong fungistatic and fungicidal effect. Penicillium digitatum, Penicillium italicum and Geotrichum candidum; the major fungi responsible for post-harvest spoilage of citrus and apple were inhibited with 2-6 $\mu 1 . \mathrm{L}^{-1}$ of citral vapor and its isomers: geranial and neral (26). Also, blue mold rot in apples (Penicillium expansum) was strongly inhibited by this natural compound (25).

In general, the inhibitory action of citral and related compounds such as citronellal and $\alpha$-pinene on mould cells involves cytoplasm granulation, cytoplasmic membrane rupturing and inactivation and/or synthesis inhibition of intracellular and extracellular enzymes. These actions can occur in an isolate or concomitant way and culminate with mycelium germination inhibition (4).

Essential oil of Bupleurum gibraltarium aerial parts containing $15.6 \%$ of $\alpha$-pinene inhibits Plasmopara halstedii sporulation at a concentration of $5.0 \mathrm{ml} \cdot \mathrm{L}^{-1}(6)$. This pinene also inhibits B1 aflatoxin production by A. flavus (3) and Rhizoctonia

\footnotetext{
*Corresponding Author. Mailing address: Av. Marechal Campos, 1468, 29040-090, Vitória, ES, Brasil. E-mail: biotecnologia.ufes@gmail.com
} 
solani growth (5). $\alpha$-pinene production as plant defense mechanism in pine was also described by Hofstetter et al., 2005 against ectosymbiont fungi Entomocorticium sp. and Ophiostoma minus.

Banana, papaya and pineapple are the most consumed tropical fruits in the world, produced in large scale in Brazil. A great importance has been given to minimize the use of pesticides in the globalized agriculture business. Therefore, results with natural products will increase the alternatives in control tropical fruits post-harvest losses. An important matter to the under consideration is that active essential oils cause severe damage to fruit skin. Therefore, the choice of the oil solvent and proper dilution is the key for practical use of this technology. In the present study we have evaluated the antifungal properties of monoterpenes citral, citronellal, Lcarvone, isopulegol and $\alpha$-pinene on Colletotrichum gloeosporioides, Colletotrichum musae and Fusarium subglutinans f.sp. ananas, food born phytopathogens widely distributed in nature, that cause papaya and banana anthracnose as well as fusarium fruit rot of pineapple. Bioassay was also performed on these tropical fruits using the monoterpene citral as natural preservative. The inhibitory effect is compared within the monoterpenes and with that of a synthetic commercial fungicide and the results are discussed.

\section{MATERIALS AND METHODS}

\section{Phytopathogens Fungi}

The fungi used in this work, Colletotrichum musae (E-366), Colletotrichum gloeosporioides (E-368) and Fusarium subglutinans f.sp. ananas (NRRL25624), were derived from single conidia and are available at the INCAPER Plant Pathology Laboratory, ES, Brazil. All cultures were routinely infected in fruits and re-isolated to retain their infectiveness and maintained on potato-dextrose-agar (PDA) (Oxoid Unipath Ltda., Basingstoke, Hampshire, UK) slants. The isolates were identified using morphology and colony growth methodology (24).

\section{Determination of antimicrobial activities of the essential oils: Inhibition of mycelial growth and conidial germination in vitro tests}

The monoterpenes used in the present work; citral, citronellal, L-carvone, isopulegol and $\alpha$-pinene, supplied by Dragoco Perfumes e Aromas Ltda, SP, Brazil, were diluted in ethanol (Sigma Chem. Co, MO, USA) and brought to final concentrations of 0.2 , 0.4, 0.6, 0.8 and $1 \%$ (v/v) in PDA Petri dishes. As negative control, commercial mineral oil (União Química Farmacêutica S.A., SP, Brazil) and ethanol (Sigma Chem. Co, MO, USA) were used. A synthetic commercial fungicide containing 50\% benomyl (Benlate ${ }^{\circledR} 500$ PM from DuPont Brazil, SP, Brazil) at a concentration of $0.1 \%$ was used as a positive control, as the three fungal strains represent populations that are still sensitive to benomyl. Four replications were used for each oil concentration and the experiments were conducted twice.

To determinate the antifungal activity, a $5 \mathrm{~mm}$ disk of mycelium of each fungus, grown on PDA for 7 days, was inoculated in the center of each individual PDA/monoterpene Petri-dish. The dishes were incubated at room temperature (26 $\pm 2^{\circ} \mathrm{C}$ ) and mycelial growth was evaluated by measurements of colony diameter until 10 days of incubation, every two days.

For the germination test, $10 \mu \mathrm{l}$ of conidia suspension of each fungus was spread in a $70 \mathrm{~mm}$ diameter Petri-dishes containing different concentrations of the monoterpenes in PDA solid media. The dishes were incubated at room temperature for 8 hours. The number of germinated conidia was then assessed by microscopic observation using a Leica model DMLS optical microscope (Leica Microsystems, Wetzlar, Germany).

\section{Determination of essential oils effect on hyphal morphology}

Hyphae morphology evaluation of the three fungi was performed by optical microscopic observation followed by image capture and analysis using a digital camera (Moticam 2000) and Motic Images Plus software (Motic China Group Co., Xiamen, China). Each fungus at a concentration of $10^{5}$ conidia/ $\mathrm{ml}$ in BD media was treated with \% citral (v/v) for 24 and $48 \mathrm{~h}$. The material was stained with Amann lactophenol-cotton blue and mounted in 50\% glycerol for mycelia observation and examined under a Leica optical microscope. All measurements are given as the average of 10 of each structure observed.

\section{Bioassay}

Papaya (cv. Golden) and pineapple (cv. Perola) were harvested at commercial maturity, disinfected with $200 \mathrm{ppm}$ chlorine solution and rinsed with distilled water. Fruits were wounded with a sterile nail (one wound per fruit, in the equatorial zone). To determine the in vivo efficacy of the oil against the fungi, $10 \mu \mathrm{l}$ of conidia suspension of $C$. gloeosporioides or $C$. musae, adjusted to $1.0 \times 10^{6}$ spores. $\mathrm{ml}^{-1}$ was individually inoculated on the surface of papaya or pineapple, respectively. The monoterpene citral was emulsified with soy lecithin $(2.5 \%$ $\mathrm{v} / \mathrm{w})$ to a final concentration of $1 \%(\mathrm{v} / \mathrm{v})$. After 12 hours of inoculation, fruits were treated by immersion in the citral formulation. The fruits were incubated at room temperature (26 $\pm 2^{\circ} \mathrm{C}$ ) and the incidence of infected wounds evaluated after 7 days. All experiments were carried out with 5 replicates per treatment and untreated fruits or treated with lecithin $(2.5 \% \mathrm{v} /$ w) were used as controls.

\section{Statistical analysis}

Analysis of variance was performed on the SAEG-4.0 (SAEG, Brazil). Means for groups in homogeneous subsets were considered. Duncan's multiple range test was applied to determine whether differences between treatments were significant at the $\mathrm{P}=0.05$ level. 


\section{RESULTS AND DISCUSSION}

Monoterpenes constitute purified form of essential oils, having differences in their chemical functional groups (10). Two monoterpenes (citral and citronellal) with an aldehyde functional group, and one (L-carvone) with a ketone functional group showed a potent fungicidal activity against the three tested phytopathogenic fungi. At concentrations of $0.6 \%$ or above, citral completely prevented mycelium growth of $C$. musae, $C$. gloeosporioides and $F$. s. f.sp. ananas (Table 1).

Benomyl, a fungicide used for the control of banana and papaya anthracnose (15) and pineapple fusariosis, was used as a positive control and proved to inhibit $100 \%, 61 \%$ and $83 \%$ of mycelium growth of $C$. musae, $C$. gloeosporioides and $F$. s. f.sp. ananas, respectively. Comparing with the monoterpenes tested, concentrations of $1 \%$ of citronellal and L-carvone completely inhibited mycelium growth of $C$. musae and $C$. gloeosporioides and showed an inhibition of approximately $80 \%$ of $F$. subglutinans f.sp. ananas mycelium growth (Table 1). Those results are in accordance with others from the literature which observed a markedly inhibition of mycelium proliferation caused by citronellal in various fungi (19).

Isopulegol and $\alpha$-pinene have an alcohol and hydrocarbon functional group, respectively, being suggested that fungicidal efficiency of $1 \mathrm{R}, 2 \mathrm{~S}, 5 \mathrm{R}$-isopulegol could be probably do to presence of an oxygenated function in its framework (11). As indicated in Table 1 isopullegol and $\alpha$-pinene showed a low mycelium growth inhibition, results in agreement with studies from Angioni et al., 2004 and Duru et al., 2003, which showed a weak activity of essential oils with $\alpha$-pinene as major compound toward Fusarium sp. These results led us to exclude these monoterpenes from the study of conidia germination inhibition.

Shift from spore to mycelium is the key to fruit disease establishment. Discover products able to destroy plant pathogens still under spore form are important tool to the agrobusiness productive chain. Germination tests with the three monoterpenes that conferred the best results on the mycelium growth inhibition screening were conducted at the same dilutions used for the mycelial inhibition test. Citral at $0.4 \%$ exhibited maximum activity to all fungi and no other monoterpene at the same concentration tested equaled it. Citral and citronellal at a concentration of $0.2 \%$ and L-carvone at $0.4 \%$ completely inhibited C. musae and C.gloeosporioides germination. F. subglutinans f.sp. ananas germination was completely inhibited by $0.4 \%$ citral, $0.6 \%$ citronellal and $0.8 \%$ L-carvone. In comparison to the monoterpenes, the fungicide benomyl showed lower inhibition of conidia germination (maximum inhibition of $79 \%$ to C. musae, $37 \%$ to $C$. gloeosporioides and $42 \%$ to $F$. $s$. f.sp. ananas.). These results indicate that those monoterpenes cause severe damage to conidia even at lower concentrations.

Studies using advanced techniques have looked at damage effects caused by citral at cellular structures of fungi, like membranes, organelles and intracellular macromolecules. In Aspergillus flavus spores, citral causes a direct damage in cell wall and membrane, decreasing their elasticity and volume due to an induction of malondialdehyde (MDA), which tends to interact with membrane proteins amino groups (8). In a previous work, Luo et al., 2001 stated that in the presence of citral the electric conductivity of A. flavus membrane increases, activity of $\left[\mathrm{Na}^{+}, \mathrm{K}^{+}\right]$-ATPase decreases, as well as the rate of proteins and sugars mobilization.

After entering cell, citral affects biological oxidations and TCA cycle not only influencing the genetic expression of mitochondrion replication and its morphology, but also producing crowding which causes non-functional aggregation of protein-like macromolecules, leading to metabolic disorders (8). As a result, cells, organelles and macromolecules of A. flavus loose their normal structures and functions, eventually leading to inhibition of sporulation and mycelial growth at concentrations of 2.8 and $3.46 \mathrm{mg} \cdot \mathrm{ml}^{-1}$, respectively, as well as completely inhibited aflatoxin production at $0.1 \mathrm{mg} \cdot \mathrm{ml}^{-1}$ (13). Similar results were also obtained for A. parasiticus treated with thyme oil (16).

Microscopic observations showed that citral altered the hyphae morphology of the three studied fungi compared to control hyphae (Fig. 1). A reduction on hyphal width was observed after $1 \%$ citral treatment. Under the influence of this monoterpene there was an alteration on mycelia growth and $C$.

Table 1. Minimal inhibitory concentration of five monoterpenes extracted from plant essential oils on mycelial growth of three phytopathogenic fungi.

Concentration (\%) to $100 \%$ inhibition

\begin{tabular}{lccccc}
\cline { 2 - 5 } & Citral & Citronellal & L-carvone & Isopulegol & $\alpha$-pinene \\
\hline C. gloeosporioides & 0.6 & 1.0 & 1.0 & $>1.0$ & $\mathrm{NI}$ \\
C. musae & 0.6 & 0.6 & 0.8 & $>1.0$ & $>>1.0$ \\
F. s. fsp. ananas & 0.6 & $>1.0$ & $>1.0$ & $>1.0$ & $>1.0$ \\
\hline
\end{tabular}

NI - no inhibition observed. 


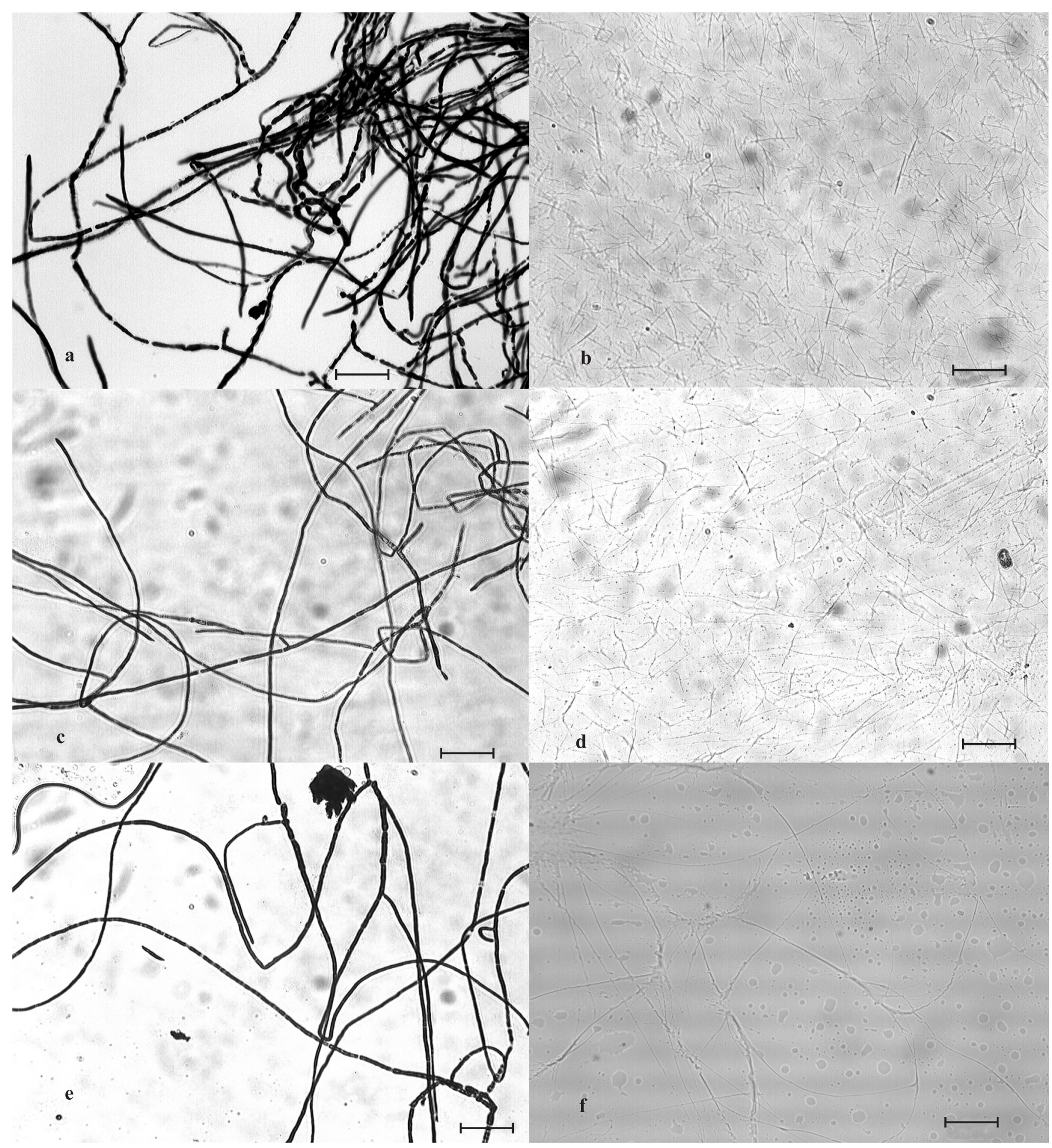

Figure 1. Effect of 1\% citral on hyphal morphology of three phytopathogenic fungi: (a), (c), (e) Hyphae growing on control medium and (b), (d), (f) $48 \mathrm{~h}$ treated mycelium stained with lactophenol blue of (a) and (b) Colletotrichum gloeosporioides, (c) and (d) Colletotrichum musae and (e) and (f) Fusarium subglutinans f.sp. ananas. Bars corresponds to $30 \mu \mathrm{m}$. 
gloeosporioides, F. s. f.sp. ananas and C. musae hyphae were $70 \%, 70 \%$ and $60 \%$ narrower, respectively, than the untreated control fungi (Table 2). It is worth to notice that when comparing 24 or $48 \mathrm{~h}$ incubation with or without citral there was no difference between the performed measurements (Table 2). Similar alterations were observed in Penicillium digitatum in experiments with Thymus capitatus essential oils (2) and in Phytophthora infestans treated with several essential oils (21).

After testing the in vitro essential oils effectiveness, it was important to verify the same property in whole fruits. Therefore, experiments were carried out at which commercial banana, papaya and pineapple fruits, prior inoculated with the specific fungi, were treated with citral. Significant difference among the fruits treated with $1.0 \%$ citral was observed after seven days. There was a $70 \%$ reduction of the lesion diameter on citral treated papaya fruits when compared to the untreated ones or to fruits treated just with the dispersant lecithin. Papaya fruit peduncle rot was also reduced with citral treatment in comparison to untreated fruit (Fig. 2). Similar results were also seen for bananas infected with $C$. musae treated in the same manner with citral where there was a $60 \%$ reduction on the lesion diameter (data not shown).

Studies regarding the antimicrobial activity of essential oils in food matrix had been published, such as an evaluation of the effectiveness of oregano (Origanum vulgare) essential oil on ground meat. The oil solution was uniformly poured on the meat and was able to decrease the autochthonous bacterial flora (20). Nevertheless, it is important to note that the direct contact of pure essential oil with the delicate fruits skin causes toxicity and the use of a dispersant such as lecithin is crucial. Also, another work showed the efficacy of plant essential oils as fumigants for control of blue mold (caused by $P$. expansum) on pear fruit. The treatment was performed for $24 \mathrm{~h}$ at $20^{\circ} \mathrm{C}$ and the fruits were placed inside a sealed cabinet at which the volatile compounds were injected (12). As far as good control of blue mold was obtained by this method, other studies points out that essential oils will release mixed volatile compounds (VOCs) and many of these, such as terpenes and D-limonene, have a significant role in the formation of secondary organic aerosols (SOA) after oxidation, often more irritating and allergenic than

Table 2. Hyphae width of three phytopathogenic fungi treated with $1 \%$ citral compared to the untreated control.

\begin{tabular}{clccc}
\hline \multirow{2}{*}{$\mathrm{L}(\mu \mathrm{m})$} & C. gloeosporioides & C. musae & $\begin{array}{l}\text { F.s.fsp. } \\
\text { ananas }\end{array}$ \\
\hline \multirow{2}{*}{$24 \mathrm{~h}$} & control & $3.9 \pm 0.7$ & $2.6 \pm 0.3$ & $2.8 \pm 0.3$ \\
& treated & $1.1 \pm 0.2$ & $0.8 \pm 0.1$ & $0.8 \pm 0.2$ \\
\multirow{2}{*}{$48 \mathrm{~h}$ h control } & $3.4 \pm 0.5$ & $2.5 \pm 0.5$ & $3.3 \pm 0.6$ \\
& Treated & $1.0 \pm 0.2$ & $1.2 \pm 0.1$ & $1.0 \pm 0.3$ \\
\hline
\end{tabular}

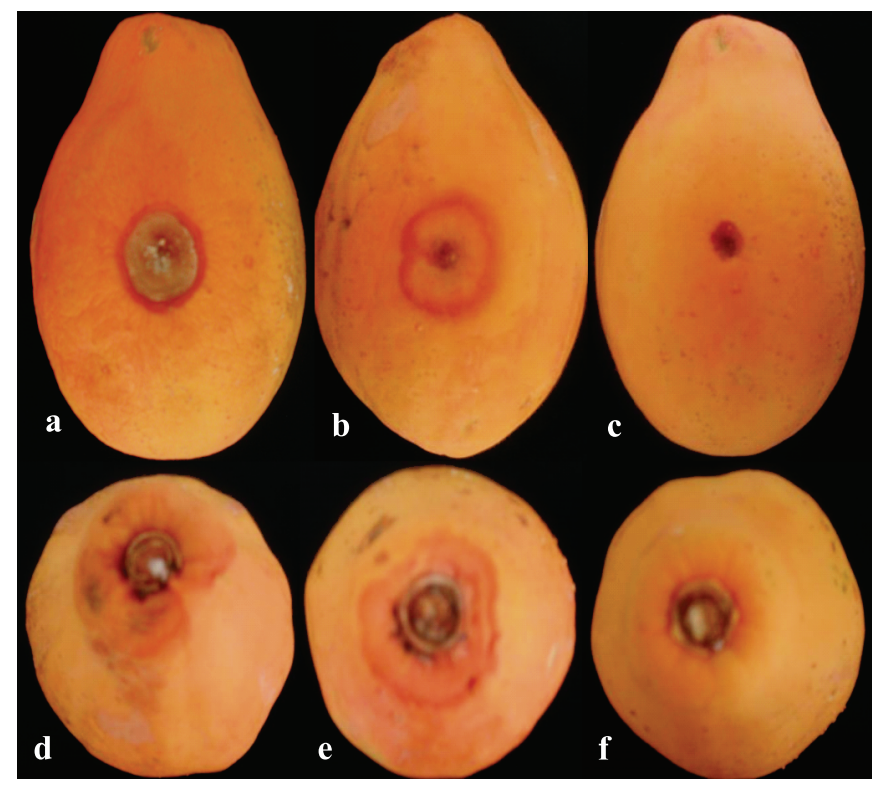

Figure 2. In vivo determination of the antimicrobial activity of citral monoterpene in papaya cultivar Sunrise-Solo, 7 days after inoculation with a $C$. gloeosporioides conidia suspension. (a), (b) and (c) represent anthracnose lesion; (d), (e) and (f) represent rot peduncunlar disease; (a) and (d) are the untreated control; (b) and (e) are the controls treated with $2.5 \%$ lecithin and (c) and (f) are fruits treated with $1 \%$ citral dispersed in lecithin.

the original substance, suggesting care on the exposure to this substances from the air. Actually, even though the emission pattern varies, most VOCs in essential oils would emit into the air within the first $30 \mathrm{~min}$ (22).

These experiments lead us to conclude that citral is highly effective in the control of the three phytopathogenic fungi tested, and indicate its potential use for post-harvest disease control. As a sustainable agriculture alternative, it is valuable to screen plant extracts, available at low cost, with citral as the main essential oil constituent. Such oils may be used in management strategies to control fungi diseases, minimizing the environmental impacts caused by synthetic fungicides. We understand that it is also very important to have these oils evaluated under field and packinghouse conditions.

\section{ACKNOWLEDGMENTS}

We thank Dr. A.C. Chiaradia for helping with essential oils solutions preparation. This work was supported by grants from FINEP (Financiadora Nacional de Estudos e Projetos), CNPq (Conselho Nacional de Desenvolvimento Científico e Tecnológico) and FUNCITEC (Fundo Estadual de Ciência e Tecnologia do Espírito Santo). 


\section{RESUMO}

\section{Atividade antimicrobiana e uso potencial de monoterpenos como preservantes de furtas tropicais}

Banana, mamão e abacaxi são as frutas tropicais mais consumidas no mundo, sendo o Brasil um dos principais produtores. Os fungos Colletotrichum musae, Colletotrichum gloeosporioides e Fusarium subglutinans f.sp ananas são os principais causadores de doenças e perdas em pós-colheita de frutas. A proposta deste estudo foi avaliar a eficácia de cinco monoterpenos em inibir o crescimento micelial e a germinação dos conídios destes três fitopatógenos. Os monoterpenos citral, citronelal, L-carvona, isopulegol e $\alpha$-pineno foram diluídos em etanol à concentração final de $0,2 \mathrm{a} 1 \%$. Todos os monoterpenos testados inibiram os três fungos estudados de maneira dosedependente. Citral foi o mais efetivo dos óleos testados e apresentou uma potente atividade fungicida em concentrações acima de $0,5 \%$. Mais ainda, avaliação in vivo com estas frutas tropicais demonstrou a eficácia de citral como inibidor do crescimento fúngico. Estes resultados indicam o uso em potencial de citral como um pesticida natural no controle das doenças em pós-colheita de frutas tropicais.

Palavras-chave: controle biológico, óleos essenciais, banana, mamão, abacaxi, doenças de plantas

\section{REFERENCES}

1. Angioni, A.; Barra, A.; Cereti, E.; Barile, D.; Coisson, J.; Arlorio, M.; Dessi, S.; Coroneo, V.; Cabras, P. (2004). Chemical composition, plant genetic differences, antimicrobial and antifungal activity investigation of the essential oil of Rosmarinus officinalis L. J. Agric. Food Chem., 52(11), 3530-3535.

2. Arras, G.; Usai, M. (2001). Fungitoxic activity of 12 essential oils against four postharvest citrus pathogen, chemical analysis of Thymmus capitatus oil and its effect in sub atmospheric pressure conditions. J. Food Protect., 64, 1025-1029.

3. Cosentino, S.; Barra, A.; Pisano, B.; Cabizza, M.; Pirisi, F.; Palmas, F. (2003). Composition and antimicrobial properties of Sardinian juniperus essential oils against foodborne pathogens and spoilage microorganisms. J. Food Prot., 66(7), 1288-1291.

4. Cowan, M. (1999). Plants products as antimicrobial agents. Clin. Microbiol. Rev., 12, 564-582.

5. Duru, M.; Cakir, A.; Kordali, S.; Zengin, H.; Harmandar, M.; Izumi, Z.; Hirata, T. (2003). Chemical composition and antifungal properties of essential oils of three Pistacia species. Fitoterapia, 74(1-2), 170-176.

6. Fernández-Ocaña, A.; Gómez-Rodríguez, M.; Velasco-Negueruela, A.; Camacho-Simarro, A.; Fernández-López, C.; Altarejos, J. (2004). In vivo antifungal activity of the essential oil of Bupleurum gibraltarium against Plasmopara halstedii in sunflower. J. Agric. Food Chem., 52(21), 6414-6417.

7. Hofstetter, R.; Mahfouz, J.; Klepzig, K.; Ayres, M. (2005). Effects of tree phytochemistry on the interactions among endophloedic fungi associated with the southern pine beetle. J. Chem. Ecol., 31, 539-560.

8. Luo, M.; Jiang, L.; Huang, Y.; Xiao, M.; Li, B.; Zou, G. (2004). Effects of citral on Aspergillus flavus spores by quasi-elastic light scattering and multiplex microanalysis techniques. Acta Biochim. Biophys. Sin., 36(4), 277-283.

9. Luo, M.; Jiang, L.; Wu, Z. (2001). Preliminary study on citral impairs the Aspergillus flavus membrane. Acta Microbiol. Sin., 41(6), 723729.

10. Mimica-Dukic, N.; Bozin, B.; Sokovic, M.; Simin, N. (2004). Antimicrobial and antioxidant activities of Melissa officinalis L. (Lamiaceae) essential oil. J. Agric. Food Chem., 52(9), 2485-2489.

11. Naigre, R.; Kalck, P.; Roques, C.; Roux, I.; Michel, G. (1996). Comparison of antimicrobial properties of monoterpenes and their carbonylated products. Planta Med., 62(3), 275-277.

12. Neri, F.; Mari, M.; Brigati, S. (2006). Control of Penicillium expansum by volatile compounds. Plant Pathology, 55, 100-105.

13. Paranagama, P.; Abeysekera, K.; Abeywickrama, K.; Nugaliyadde, L. (2003). Fungicidal and anti-aflatoxigenic effects of the essential oil of Cymbopogon citratus (DC.) Stapf. (lemongrass) against Aspergillus flavus Link. isolated from stored rice. Lett. Appl. Microbiol., 37(1), 86-90.

14. Parveen, M.; Hasan, K.; Takahashi, J.; Murata, Y.; Kitagawa, E.; Kodama, O.; Iwahashi, H. (2004). Response of Saccharomyces cerevisiae to a monoterpene: evaluation of antifungal potential by DNA microarray analysis. J. Antimicrob. Chemother, 54(1), 46-55.

15. Perera, O.; Karunaratne, A. (2000). Response of bananas to postharvest acid treatments. J. Hort. Sci. Biotechnol., 76(1), 70-76.

16. Rasooli, I.; Owlia, P. (2005). Chemoprevention by thyme oils of Aspergillus parasiticus growth and aflotoxin production. Phytochem., 66, 2851-2856.

17. Sartoratto, A.; Machado, A.L.M.; Delamerlina, C.; Figueira, G.M.; Dubiarte, M.C.T.; Rehder, V.L. (2004). Composition and antimicrobial activity of essential oils from aromatic plants used in Brazil. Braz. J. Microbiol., 35, 275-280.

18. Shimizu, M.T.; Bueno, L.J.F.; Rodrigues, R.F.O.; Sallowicz, F.A.; Sawaya, A.C.H.F.; Marques, M.O.M. (2006). Essential oil from Lithraea molleoides (Vell.): chemical composition and antimicrobial activity. Braz. J. Microbiol., 37, 556-560.

19. Souza, E.; Lima, E.; Freire, K.; Sousa, C. (2005). Inhibitory action of some essential oils and phytochemicals on the growth of various moulds isolated from foods. Braz. Arch. Biol. Technol., 48(2), 245-250.

20. Souza, E.; Stamford, T.L.M.; Lima, E.O. (2006). Sensitivity of spoiling and pathogen food-related bacteria to Origanum vulgare L. (Lamiaceae) essential oil. Braz. J. Microbiol., 37, 527-532.

21. Soylu, E.M.; Soylu, S.; Kurt, S. (2006). Antimicrobial activities of the essential oils of various plants against tomato late blight disease agent Phytophthora infestans. Mycopathologia, 161, 119-128.

22. Su, H.; Chao, C.; Chang, H.; Wu, P. (2007). The effects of evaporating essential oils on indoor air quality. Atmospheric Environment, 41, 1230-1236.

23. Suhr, K.; Nielsen, P. (2003). Antifungal activity of essential oils evaluated by two different application techniques against rye bread spoilage fungi. J. Appl. Microbiol., 94(4), 665-674.

24. Ventura, J.A. (2000). Taxonomia de Fusarium e seus segredos. Parte II: Chaves para identificação. Ver. An. Patol. Plantas 102, 303-338.

25. Venturini, M.; Blanco, D.; Oria, R. (2002). In vitro antifungal activity of several antimicrobial compounds against Penicillium expansum. J. Food Prot., 65(5), 834-839.

26. Wuryatmo, E.; Klieber, A.; Scott, E. (2003). Inhibition of citrus post-harvest pathogens by vapor of citral and related compounds in culture. J. Agric. Food Chem., 51(9), 2637-2640. 